\title{
Management of Engineering Projects
}


Other Macmillan titles of interest to Mechanical Engineers

Mechanical Reliability, second edition

A. D. S. Carter

Elementary Engineering Mechanics

G. E. Drabble

Principles of Engineering Thermodynamics, second edition

E. M. Goodger

Polymer Materials: An Introduction for Technologists and Scientists

Christopher Hall

Introduction to Enginering Materials, second edition

V. John

Strength of Materials, third edition

G. H. Ryder

Mechanics of Machines

G. H. Ryder and M. D. Bennett

Engineering Heat Transfer, second edition

J. R. Simonson

Introduction to Internal Combustion Engines

Richard Stone

Essential Solid Mechanics-Theory, worked examples and problems

B. W. Young

\section{Other Macmillan titles of interest to Civil Engineers}

An Introduction to Engineering Fluid Mechanics

J. A. Fox

Prestressed Concrete Design by Computer

R. Hulse and W. H. Mosley

Reinforced Concrete Design by Computer

R. Hulse and W. H. Mosley

Civil Engineering Materials, third edition

edited by N. Jackson

Reinforced Concrete Design, third edition

W. H. Mosley and J. H. Bungey

Microcomputer Applications in Structural Engineering

W. H. Mosley and W. J. Spencer

Strength of Materials, third edition

G. H. Ryder

Surveying for Engineers

J. Uren and W. F. Price 


\title{
Management of Engineering Projects
}

\author{
Edited by \\ Richard Stone \\ Brunel University, \\ Uxbridge, Middlesex
}

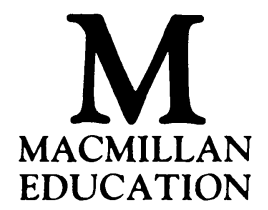


Chapters 1, 2 and 6 (C) Richard Stone 1988

Chapters 3, 4, 5, 7, 8 and 9 (C) Macmillan Education 1988

All rights reserved. No reproduction, copy or transmission of this publication may be made without written permission.

No paragraph of this publication may be reproduced, copied or transmitted save with written permission or in accordance with the provisions of the Copyright Act 1956 (as amended), or under the terms of any licence permitting limited copying issued by the Copyright Licensing Agency 33-4 Alfred Place, London WC1E 7DP.

Any person who does any unauthorised act in relation to this publication may be liable to criminal prosecution and civil claims for damages.

First published 1988

Published by

MACMILLAN EDUCATION LTD

Houndmills, Basingstoke, Hampshire RG21 2XS

and London

Companies and representatives

throughout the world

British Library Cataloguing in Publication Data

Management of engineering projects.

1. Engineering-Management

I. Stone, Richard, 1955

$620^{\prime} .0068^{\prime} 4 \quad$ TA190

ISBN 978-0-333-40959-6 ISBN 978-1-349-19572-5 (eBook)

DOI 10.1007/978-1-349-19572-5 


\section{Contents}

Preface $\quad x i$

Notes on Contributors xiii

Notation $\quad$ Xv

PART I: PRINCIPLES, TECHNIQUES AND MANAGEMENT 1

1 Introduction 3

1.1 The Background to Project Engineering 3

1.2 Project Identification and Development 5

$\begin{array}{llr}1.3 & \text { Project Evaluation } & 9\end{array}$

$\begin{array}{lll}1.4 & \text { Project Execution } & 12\end{array}$

$\begin{array}{llr}1.5 & \text { Project Auditing } & 15\end{array}$

$\begin{array}{lll}1.6 & \text { Conclusions } & 16\end{array}$

$\begin{array}{lll}1.7 & \text { Discussion Questions } & 18\end{array}$

2 Project Timing and Financial Control 19

$\begin{array}{ll}2.1 & \text { Introduction } \\ 2.2 & 19\end{array}$

2.2 Project Timing 20

$\begin{array}{lll}2.2 .1 \quad \text { Introduction } & 20\end{array}$

$\begin{array}{lll}2.2 .2 & \text { Bar Charts } & 21\end{array}$

$\begin{array}{lll}2.2 .3 & \text { Network Analysis } & 25\end{array}$

2.2.4 Resource Levelling $\quad 32$

2.2.5 Computer Based Systems and a Comparison between Bar Charts and Network Analysis $\quad 35$ 
2.3 Financial Control $\quad 38$

$\begin{array}{lll}2.3 .1 & \text { Estimating } & 38\end{array}$

2.3.2 Controlling Purchased Goods 38

2.3.3 Integration of Progress and Financial Monitoring $\quad 40$

2.3.4 Financial Contingency Planning $\quad 42$

2.4 Conclusions $\quad 43$

2.5 Discussion Questions $\quad 44$

3 Management of Engineering Projects 46

$\begin{array}{lll}3.1 & \text { Introduction } & 46\end{array}$

3.2 Organisation Design for Projects 46

3.2.1 Background 46

3.2.2 The Different Types of Matrix Organisation 50

$\begin{array}{ll}\text { 3.2.3 The Matrix Structure in Practice } & 51\end{array}$

3.2.4 Making Matrix Methods Work $\quad 56$

3.3 The Project Management Task $\quad 58$

$\begin{array}{lll}\text { 3.3.1 Introduction } & 58\end{array}$

3.3.2 Establishing the Project Brief 59

3.3.3 Defining the Role of the Project Manager 59

$\begin{array}{ll}\text { 3.3.4 The Management of Design } & 60\end{array}$

3.3.5 The Management of Design Implementation 62

3.3.6 Attributes of the Project Manager 62

3.4 Project Teams and their Leadership 64

3.4.1 The Purpose of Project Teams 64

3.4.2 The Assessment and Formation of Project Teams 66

3.4.3 Project Team Leadership $\quad 67$

$\begin{array}{lll}3.5 & \text { Summary and Conclusions } & 70\end{array}$

$\begin{array}{lll}3.6 & \text { Discussion Questions } & 72\end{array}$

PART II: LEGAL ASPECTS

4 Contractors and Contract Law 75

4.1 Introduction $\quad 75$

4.2 Contracts and Contractors $\quad 76$

4.2.1 Forms of Contract $\quad 76$

4.2.2 Criteria for Selecting Contractors $\quad 80$

4.2.3 Contractor Motivation $\quad 83$

4.3 General Principles of Contract $\quad 85$

4.3.1 Offer and Acceptance $\quad 86$

4.3.2 The Battle of the Forms $\quad 87$

4.3.3 Form and Content-Terms $\quad 87$

$\begin{array}{lll}\text { 4.3.4 Misrepresentation } & 88\end{array}$ 
4.3.5 Privity of Contract $\quad 89$

4.3.6 Frustration and Force majeure $\quad 89$

$\begin{array}{ll}\text { 4.3.7 Agency } & 90\end{array}$

4.4 Suppliers' Duties-Goods $\quad 91$

4.4.1 Types of Supply Contracts $\quad 92$

$\begin{array}{lll}\text { 4.4.2 Strict Liability } & 92\end{array}$

4.4.3 Description and Specifications 93

4.4.4 Quality and Fitness $\quad 94$

4.5 Suppliers' Duties-Services $\quad 96$

4.5.1 Duty of Care 96

$\begin{array}{lll}4.5 .2 & \text { Time } & 97\end{array}$

$\begin{array}{lll}\text { 4.5.3 Charges } & 97\end{array}$

4.6 Damages and Other Remedies 98

4.6.1 Termination/Cancellation $\quad 98$

$\begin{array}{ll}\text { 4.6.2 Acceptance } & 98\end{array}$

4.6.3 Damages $\quad 99$

$\begin{array}{ll}\text { 4.6.4 Exchange } & 101\end{array}$

4.6.5 Specific Performance 101

$\begin{array}{ll}\text { 4.6.6 Misrepresentation } & 101\end{array}$

4.6.7 Liquidated Damages and Penalties 102

4.7 Exemption Clauses-The Unfair Contract Terms Act
1977

$\begin{array}{lll}\text { 4.7.1 Introduction } & 103\end{array}$

4.7.2 The Reasonableness Test 104

$\begin{array}{lll}4.8 & \text { Product Liability } & 106\end{array}$

$\begin{array}{lll}4.9 & \text { Conclusions } & 106\end{array}$

$\begin{array}{ll}4.10 \text { Discussion Questions } & 107\end{array}$

5 Safety and Risk 109

$\begin{array}{ll}\text { 5.1. Introduction } & 109\end{array}$

$\begin{array}{ll}5.2 \text { Technical Legal Matters } & 110\end{array}$

$\begin{array}{lll}5.2 .1 & \text { Sources of Law } & 110\end{array}$

5.2.2 Courts of Law (and Tribunals) 112

$\begin{array}{ll}\text { 5.3 The Background to the Legal Structure } & 112\end{array}$

$\begin{array}{ll}\text { 5.3.1 The Objectives of the Law } & 112\end{array}$

5.3.2 The History of the Law 113

5.3.3 The Robens Committee 114

5.4 The Modern Institutional Framework 115

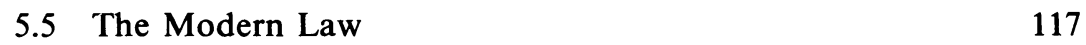

$\begin{array}{lll}\text { 5.5.1 Preliminary Points } & 117\end{array}$

5.5.2 The Health and Safety at Work Act 1974

5.5.3 Duties of Employers towards their Employees 119 
5.5.4 Duties Imposed on Employees

5.5.5 Duties Imposed on Others

5.5.6 Powers of Enforcement 121

5.6 Other Statutory Provisions 122

5.6.1 The Factories Act $1961 \quad 122$

5.6.2 Fire Precautions Act $1971 \quad 123$

5.6.3 Other Legislation and Quasi-legal Standards 123

5.7 The Common Law 124

$\begin{array}{lll}\text { 5.7.1 Negligence } & 124\end{array}$

5.7.2 Breach of Statutory Duty 124

$\begin{array}{lll}5.8 \text { Risk } & 125\end{array}$

$\begin{array}{ll}5.9 \text { Design for Safety } & 129\end{array}$

5.10 Conclusions 133

5.11 Discussion Questions 133

PART III: CASE STUDIES 135

6 The Planning of New Facilities 137

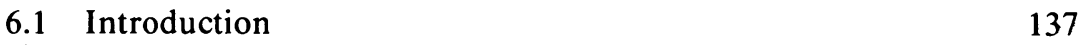

$\begin{array}{lll}6.2 & \text { Site Selection } & 138\end{array}$

6.2.1 Introduction 138

6.2.2 Minimisation of Transport Costs 140

6.3 Finance for New Facilities 141

6.4 Checklists for New Facilities 145

6.5 Conclusions 147

6.6 Discussion Questions 148

7 Computer Projects 149

7.1 Introduction 149

$\begin{array}{lll}7.2 & \text { Project Organisation } & 150\end{array}$

7.3 The Functional Specification 152

7.4 Project Planning 153

7.5 Design 156

$\begin{array}{ll}7.6 & \text { Implementation }\end{array}$

$\begin{array}{lll}7.7 & \text { Testing } & 160\end{array}$

$\begin{array}{lll}7.8 & \text { Documentation } & 162\end{array}$

$\begin{array}{lll}7.9 & \text { Acceptance } & 163\end{array}$

7.10 Support 163

$\begin{array}{ll}7.11 \text { Conclusions } & 165\end{array}$

$\begin{array}{ll}7.12 \text { Discussion Questions } & 166\end{array}$ 
8 A CAD/CAM Case Study $\quad 167$

$\begin{array}{lll}8.1 \text { Introduction } & 167\end{array}$

$\begin{array}{ll}\text { 8.1.1 The 'Company' } & 167\end{array}$

$\begin{array}{ll}\text { 8.1.2 Initial Study } & 168\end{array}$

$\begin{array}{ll}8.2 \text { The Justification } & 170\end{array}$

$\begin{array}{lll}\text { 8.2.1 Technical Justification } & 171\end{array}$

$\begin{array}{ll}\text { 8.2.2 Financial Justification } & 173\end{array}$

$\begin{array}{lr}\text { 8.2.3 Managerial Justification } & 180\end{array}$

$\begin{array}{ll}\text { 8.2.4 User Justification } & 181\end{array}$

$\begin{array}{ll}\text { 8.3 Planning for Installation } & 181\end{array}$

8.3.1 Formation of a Project Team 181

$\begin{array}{ll}\text { 8.3.2 Training Programme } & 181\end{array}$

8.3.3 Siting the Hardware 183

$\begin{array}{ll}\text { 8.3.4 Personnel Selection } & 184\end{array}$

$\begin{array}{ll}8.4 \text { Commissioning } & 185\end{array}$

8.4.1 Building the Database of Parts 185

$\begin{array}{ll}\text { 8.4.2 System Customisation } & 190\end{array}$

8.4.3 Utilisation and System Management 193

$\begin{array}{lll}8.5 \text { Conclusions } & 194\end{array}$

8.5.1 Capital Justification 194

$\begin{array}{lll}\text { 8.5.2 Project Evaluation } & 194\end{array}$

8.5.3 Project Management 196

8.6 Discussion Questions 196

9 A Manufacturing Case Study 198

9.1 Introduction and Product Description 198

9.2 Project Background 200

9.3 The Project Terms of Reference and the Testing Sequence 201

$\begin{array}{ll}\text { 9.3.1 The Terms of Reference } & 201\end{array}$

9.3.2 The Testing Sequence 203

9.4 Methods of Logging Information 203

9.4.1 The Philosophy behind the Testing 203

9.4.2 The Method of Logging Fault Data 204

9.4.3 Fault Logging in Practice 205

9.5 Quality Control 206

9.5.1 Introduction $\quad 206$

$\begin{array}{ll}\text { 9.5.2 Automatic Test Equipment } & 207\end{array}$

$\begin{array}{ll}\text { 9.5.3 Progress Review } & 210\end{array}$

$\begin{array}{lll}9.6 & \text { Test Procedures } & 211\end{array}$

9.7 Quality Control of Extraordinary Items 213

$\begin{array}{ll}9.8 \text { Conclusions } & 215\end{array}$

9.9 Discussion Questions 216 
$\times$ CONTENTS

Appendix A: Discounted Cash Flow Techniques for Project Evaluation 217

Appendix B: Guidelines for Reports and Presentations

Appendix C: Effective Working

Appendix D: The Laws of Project Engineering

Appendix E: The North West Corner Algorithm

References

Bibliography

Index 


\section{Preface}

A project is by definition a transient phase that contrasts with the steady state operations more frequently found in industry.

For the successful completion of an engineering project, it is not sufficient to have a sound technical input. Business and project skills are also necessary, and these form the subject of this book. Management of Engineering Projects is divided into three parts:

Part I: Principles, Techniques and Management

Part II: Legal Aspects

Part III: Case Studies

The first three chapters constitute Part I, with Chapter 1 providing definitions of the phases in a project (Definition, Justification and Execution) and their associated financial aspects. Chapter 2 covers the project skills of estimation, planning, monitoring and control-an area where the integration of time and financial management is of the highest importance. Project management is discussed in Chapter 3, where the different types of project management structure are explained, along with the way that the structure can change during the project life cycle. The equally important subject of teamwork is also covered.

Part II of Management of Engineering Projects is devoted to the legal and related aspects of projects. The legal areas covered are contract law, and health and safety legislation. As greater use has been made of the project approach, so has greater use been made of contractors. For this reason Chapter 4 is devoted to contract types and contract law. Health and safety legislation now has a much greater significance, and despite its importance in all areas of employment, it is often omitted from degree and other courses. Chapter 5 also covers the related subject of engineering risk assessment and control. 
The case studies in Part III are of two types: the first two are of a general nature, while the second two consider specific projects. Chapter 6 takes a general look at problems associated with establishing a new facility, and provides checklists to help ensure that a thorough approach is taken; Chapter 7 describes computer projects and some of their particular problems. The case studies in Chapters 8 and 9 illustrate the project techniques described earlier in the book, and they also provide insights into CAD/CAM and the subject of quality.

Discussion questions are placed at the end of each chapter. These can be used in seminars or by individual readers as a check on their understanding of what they have read. Many terms are defined in the text, and these are highlighted by an italic typeface. The terms that have. been defined in the text are also indicated in the index by a bold typeface; this enables the index to be used as a glossary.

In the text no significance should be attached to the use of 'he' or 'his'; the alternatives of 'she' and 'hers' should be taken as implicit alternatives.

This book has been developed from material used in a final year course in the Special Engineering Programme at Brunel University. Some of the material has also been used for a short course on Project Management for engineers, consequently the book is aimed at engineering students and graduates. While the book can be used with students at any level, students who have received some industrial training and management teaching will probably find it easiest to appreciate the material. In order to keep the book to a readable and usable length, some material has only been presented in outline. However, sources of further information are listed in the Bibliography, as well as a list of references.

In the same way that a project is a multi-disciplinary activity, so has been the writing of this book. The Notes on Contributors indicate the backgrounds of the authors, and their contribution is obvious. Less obvious are the contributions from the numerous engineers and industrialists who have been willing to talk to me about projects. I would like to thank all the people who have contributed directly and indirectly to this book. Finally, I must thank Jenny Shaw, Peter Murby and John Winkler of Macmillan Education for their support in this project; special thanks are also due to Dennis Radford who read and commented usefully on the entire manuscript. 


\section{Notes on Contributors}

David Birchall as Director of Graduate Studies at the Management College, Henley, is currently the Course Director of the Brunel University/Henley MSc in Project Management. He has had extensive experience of project management in construction, research and development, and in training/education. His publications include Tomorrow's Office Today published by Business Books, and many articles on work organisation, management development and project management.

(Author of Chapter 3)

Jonathan Hooker graduated from Loughborough University in Production Engineering and Management in 1979. He did two years of project engineering as described in the case study before becoming an assembly foreman, production control supervisor and finally shift supervisor. He joined Brunel University in 1984. He now works for PA Consulting Group.

(Author of Chapter 9)

Christopher Hudson is a Lecturer in Electronics and Computing in the Department of Engineering and Management Systems at Brunel University. Prior to this he was a Lecturer in the Computer Science Department at Queen Mary College (University of London), and before that he spent some 12 years in the electronics and computing industry. The industrial work was concerned with the design, implementation and management of computerised systems and projects for industry. He spent several years in the Computer Systems Group of Digital Equipment Company Ltd, where he project-managed many computer projects. His research interests are in the application of real-time systems, speech communications and aids for the disabled.

(Author of Chapter 7) 
Martin Partington is a Professor of Law at Bristol University. He has researched widely into many areas of applied public law, including social welfare, social security and the regulation of the housing market: His contribution in this volume is an extension of that interest. For a number of years he has given lectures on law (including health and safety) to engineering students.

(Author of sections 5.2-5.7)

Mark Pearson graduated from the Special Engineering Programme at Brunel University in 1982. His first appointment was as a Project Engineer within the Manufacturing Engineering Department of a specialist engineering company. He became involved with numerous engineering projects, including shopfloor data collection and the capital justification for a machine tool and a computer aided design facility. He joined a leading CAD/CAM vendor in 1983 as an Applications Engineer, and more recently he moved into a sales role where he has responsibility for the Southern District operation.

(Author of Chapter 8)

Richard Stone is a Lecturer in the Department of Manufacturing and Engineering Systems at Brunel University. His interests and experience have covered a range of engineering projects; most recently this has taken the form of research projects. His involvement with Project Engineering takes the form of running a final year option for the Special Engineering Programme at Brunel and contributions to short courses, including some tailored to specific companies.

Geoffrey Woodroffe is a solicitor and a Senior Lecturer in Law and Director of the Centre for Consumer Law Research at Brunel University. He is a consultant for the National Consumer Council, the Consumers' Association and the EEC Commission. He has lectured, written and broadcast extensively on many aspects of contract law; he is the author of several books. (Author of sections 4.3-4.8) 


\section{Notation}

$a_{i} \quad$ output from location $i$

AD activity duration

ATE automatic test equipment

$b_{j} \quad$ requirement at location $j$

BOM bill of materials

$C_{i j} \quad$ transport cost from location $i$ to $j$

CAD/CAM computer aided design, computer aided manufacture

CNC computer numerical control

CPA critical path analysis

DCF discounted cash flow

DOI Department of Industry

ECGD Export Credits Guarantee Department (part of the Department of Trade and Industry)

EEC European Economic Community

EPROM erasable programmable read only memory

ESD earliest start date

FOC Fire Officers Committee

FPA Fire Prevention Association

HSC Health and Safety Commission

HSE Health and Safety Executive

HSWA Health and Safety at Work Act

$i$

interest rate

IRR internal rate of return

LFD latest finish date 
LPG liquefied petroleum gas

$m$ learning constant

MAAPICS MAnufacturing And Production Inventory Control Systen

$n \quad$ number of sites, occurrences, years

NPV net present value

PB payback

PC personal computer

PCB printed circuit board

PERT programme evaluation and review technique

PFBC pressurized fluidized-bed combustor

$\mathrm{PV}(\mathrm{F}) \quad$ present value (factor)

$Q_{i} \quad$ quantity to be transported from existing site $i$

$r \quad$ gearing ratio (equity finance/debt finance)

RAM random access memory

$t \quad$ time

$T_{i} \quad$ transport cost per unit quantity

TC total cost

TF total float

TTC tender to contract (scheme run by the ECGD)

UCTA Unfair Contract Terms Act

USM Unlisted Securities Market

VDU visual display unit

$X_{i j} \quad$ quantity to be transported from location $i$ to $j$

Suffices

e

estimated

m most likely

n

$n$th occurrence

o optimistic

p pessimistic 